\title{
WHITE BOX TESTING PADA SISTEM MANAJEMEN PENGELOLAAN SURAT DI SEKRETARIAT REKTORAT BERBASIS WEB
}

\author{
Asep Nurdin ${ }^{1}$ Fauziah $^{2}$, Ratih Titi Komala Sari ${ }^{3}$ \\ Program Studi Informatika, Universitas Nasional \\ asepnurdin127@gmail.com¹, fauziah@civitas.unas.ac.id², ukhuwahku01@gmail.com³
}

Submitted June 11, 2021; Revised June 14, 2021; Accepted june 15, 2021

\begin{abstract}
Abstrak
Surat merupakan media komunikasi tertulis yang dibuat atau diterima oleh suatu pihak yang terkait kepada pelaksanaan suatu tugas pokok serta fungsi organisasi kepada pihak lain. Kantor Sekretariat Rektorat Universitas Nasional yang merupakan unit kerja pengelola administrasi surat menyurat pimpinan, saat ini masih menggunakan pengelolaan surat yang manual, baik dalam pencatatan, pengarsipan dan pendisposisian. Oleh karena itu, penulis merancang sistem manajemen pengelolaan surat di sekretariat rektorat berbasis Web dengan bahasa pemograman PHP dan database MYSQL yang mudah diakses secara online melalui browsing internet, dengan tujuan untuk mempermudah pegawai dalam mengelola surat, sehingga efisiensi kerja mengalami peningkatan, pendisposian menjadi lebih cepat dan akurat, serta sitem pengelolaan surat menjadi lebih teritegrasi dan terkomputerisasi. Metode white box testing digunakan dalam pengujian sistem, dimana hasil yang diperoleh bernilai sama untuk jumlah Cyclomatic Complexity city $(\mathrm{CC})=22$, Region $(\mathrm{R})=22$ dan Independent Path $=22$, maka alur logika yang ada pada sistem manajemen pengelolaan surat berbasis web ini sudah benar dan sesuai, serta bebas dari kesalahan.
\end{abstract}

Kata Kunci : manajemen pengelolaan surat, unas, website, whitebox Testing.

\begin{abstract}
Letter is a written communication medium that is made or received by a party related to the implementation of a main task and function of the organization to another party. The Office of the Secretariat of the Rectorate of the National University, which is the working unit for managing correspondence for the leadership, is currently still using manual mail management, both in recording, archiving and disposition. Therefore, the authors designed a mail management system at the secretariat of the web-based rectorate with the PHP programming language and MYSQL database that are easily accessible online via internet browsing, with the aim of making it easier for employees to manage letters, so that work efficiency has increased, disposition becomes faster. and accurate, and the mail management system is becoming more integrated and computerized. The white box testing method is used in system testing, where the results obtained are of the same value for the number of Cyclomatic Complexity City $(C C)=22$, Region $(R)=22$ and Independent Path $=22$, meaning that the logic flow of this system shows that the mail management system is based on This website is correct and appropriate, and free from logical errors.
\end{abstract}

Key Words : letter management, unas, website, whitebox testing.

\section{PENDAHULUAN}

Semakin nyata kini Perguruan tinggi diperlihatkan perkembangan akan teknologi informasi (TI) begitu pesat. Kehadiran TI dalam konteks perguruan tinggi dapat menawarkan ancaman sekaligus tantangan. TI dapat menjadi ancaman ketika Perguruan
Tinggi hanya menjadi penonton yang pasif dari akselerasi perubahan yang ditimbulkan oleh revolusi dalam bidang TI. Perguruan tinggi yang tidak adaptif terhadap akselerasi perubahan yang dimunculkan oleh "disruptive innovation" tidak akan mampu menjaga keberlangsungan (sustainability). 
Sebaliknya, perguruan tinggi bisa menjadikan TI sebagai peluang, karena TI mampu menawarkan efisiensi dan kecepatan ketika ia bisa diitegrasikan kedalam proses kegiatan administrasi suatu organisasi, seperti dalam hal manajemen pengelolaan surat menyurat.

Surat merupakan media komunikasi tertulis oleh suatu pihak yang terkait kepada pelaksanaan suatu tugas pokok serta fungsi organisasi kepada pihak lain. Surat masuk dan surat keluar merupakan dua jenis secara umum. Surat masuk yaitu surat yang masuk ke organisasi atau bagian satu organisasi, baik dari organisasi luar ataupun bagian lain di sesama organisasi. Surat keluar yaitu surat yang dibuat atau dikeluarkan satu organisasi lalu dikirim ke lain organisasi, atau dari bagian lain sesama organisasi [1]. Dan disposisi surat merupakan media instruksi kerja satu kesatuan dengan surat yang tidak terpisahkan [2].

Universitas Nasional dikenal dengan UNAS adalah suatu pendidkan tinggi di Jakarta, memiliki prosedur pengelolaan surat manual. Kantor Sekretariat Rektorat yang merupakan unit kerja yang mengelola administrasi surat menyurat pimpinan tinggi organisasi, dalam pencatatan masih manual dengan cara ditulis tangan pada suatu buku. Juga pengarsipan, dimana surat dimasukan kedalam box file disimpan dalam lemari. Dengan pencatatan dan penyimpanan manual seperti ini sangat dimungkinkan surat sulit dicari pada saat diperlukan, bahkan mungkin hilang ataupun rusak [3].

Begitupun pendisposisian, dimana surat yang memerlukan proses tindak lanjut langsung dari pimpinan seringkali terhambat, seperti ketidak beradaannya pimpinan karena tidak masuk kantor, sehingga tertundanya pengambilan keputusan.

Penelitian ini merujuk pada Moch. Hatta, dkk dengan judul Perancangan sistem informasi pengarsipan dan pendisposisian surat pada tahun 2019, menyimpulkan bahwa sistemnya mempermudah pengarsipan dan pendisposisian [4].

Sejalan dengan itu, penelitian Gusti Purnama Sari, dkk yang membahas sistem Persuratan dan disposisi elekronik tahun 2018 yang diterapkan di Universitas Jambi dinilai baik dari sisi fungsi, efisien, kehandalan dan kegunaan sistem layak [5].

Penelitian lainnya yang membahas terkait Pengelolaan Surat Menyurat di Kantor Desa Sumberdem Malang menerangkan hal serupa bahwa dengan menggunakan satu sistem proses serta pelayanan administrasi surat menyurat berjalan lebih cepat, tepat dan efektif [6].

Untuk menjamin dan mengetahui kualitas sistem yang dibuat, maka metode pengujian white box adalah metode pengujian yang digunakan. Hal ini sesuai dengan penelitian Citra Teguh Pratala dkk, pada "Pengujian White Box Aplikasi Cash Flow". Jika didalam file dihasilkan ketidaksesuaian output dengan proses yang dilakukan, maka parameter serta variable pada baris-baris program, yang terlibat satu demi satu dicek lalu diperbaiki juga di cek ulang [7].

Penulis berharap penelitian ini dapat memberi manfaat untuk memperbaiki sistem manual yang ada sehingga mempermudah pegawai Sekretariat Rektorat dalam mengelola surat, efisiensi kerja mengalami peningkatan, dan lebih akuratnya dalam pendisposisian, sehingga kedepannya pelayanan di UNAS akan menjadi terkomputerisasi. Aplikasi dirancang berbasis web yang mudah diakses secara online melalui browsing internet smartphone, sehingga pengguna (user) akan mudah mengaksesnya kapanpun dimanapun.

\section{METODE PENELITIAN}

Dalam metode penelitian ini terdiri dari beberapa tahap yaitu, studi literatur, perumusan masalah, pengembangan sistem dan penarikan simpulan. Studi literatur dilakukan untuk mengungkap berbagai teori- 
teori yang relevan dengan permasalahan yang sedang diteliti sebagai sumber data. Perumusan masalah untuk memperjelas permasalahan yang didapat dari hasil studi literatur, sehingga memudahkan dalam penyelesaian, sehingga penulis menemukan permasalahan yang dapat dirumuskan yaitu, Bagaimana membangun Sistem Manajemen Pengelolaan Surat di Sekretariat Rektorat berbasis Web. Selanjutnya pengembangan sistem penulis memakai metode waterfall dimana Waterfall merupakan salah satu pendekatan dalam SDLC (Software Developent Life Cycle) yang digunakan untuk membangun perangkat lunak dengan alur terurut dimulai dari analisis, desain, pengodean, pengujian dan pemeliharaan [8]. Dari hasil pembahasan yang didapat, dilakukan analisis hasil sebagai dasar dalam menarik kesimpulan.

Tabel 1. Alat dan Bahan Proses Penelitian

\begin{tabular}{cll}
\hline No. & \multicolumn{1}{c}{ Nama Alat } & \multicolumn{1}{c}{ Spesifikasi } \\
\hline 1 & Laptop & Asus Core i3, RAM 8GB, HD 1TB \\
2 & Sistem Operasi & Windows 10 \\
3 & Softwr Perancangan & Wondershare Endrawax, Snipping \\
4 & Softwr Pembuatan & Sublime Text 3, XAMPP \\
5 & Bahasa Program & PHP \\
6 & Database & MySQL \\
\hline
\end{tabular}

Pada tabel 1 diatas memperlihatkan alat-alat beserta spesifikasi yang digunakan peneliti untuk pembuatan sistem manajemen pengelolaan Surat di Sekretariat Universitas Nasional Berbasis Web.

\section{Sumber Data}

1) Data Primer

Dengan observasi mengamati langsung serta mewawancarai pegawai Rektorat untuk mengetahui sistem yang berjalan dan membuktikannya pada suatu rancangan baru yang akan dilakukan.

2) Data Sekunder

Mempelajari penelitian/jurnal terdahulu yang terkait dengan penelitian.

\section{HASIL DAN PEMBAHASAN}

\section{Analisa Sistem Berjalan}

Adapun berikut ini merupakan aturan bisnis sistem berjalan pengelolaan surat pada Kantor Sekretariat Universitas Nasional:

1) Proses Pengelolaan Berjalan Surat Masuk

a. Surat datang diterima oleh Staf Kantor Sekretariat Rektorat, kemudian data surat akan ditulis/ dicatat kedalam daftar buku surat masuk, kemudian staf menyiapkan/melampirkan lembar formulir disposisi.

b. Surat yang telah dicatat dan dilampirkan form disposisi, akan diserahkan kepada Kepala Kantor Sekretariat untuk pengisian disposisi.

c. Setelah terisi catatan, kemudian surat masuk berikut lembar disposisi diantar ke ruang pimpinan (Rektor) untuk diperiksa dan lembar disposisi akan ditandatangani oleh pimpinan sebagai persetujuan isi disposisi.

d. Surat masuk berikut disposisi yang telah tanda tangani pimpinan dikembalikan kepada Kantor Sekretariat Rektorat untuk di distribusikan kepada unit kerja (Badan, Biro, UPT, Kantor, Unsur Pelaksana Akademik) sesuai bidangnya yang sesuai dengan isi surat untuk ditindaklanjut.

e. Jika surat dan disposisi tidak memerlukan tindak lanjut maka surat masuk akan langsung di file pada lemari arsip.

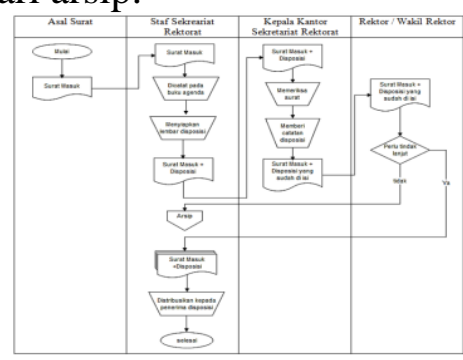

\section{Gambar 1. Flowchart Proses Berjalan Pengelolaan Surat Masuk}


2) Proses Pengelolaan Berjalan Surat Keluar

a. Asal surat keluar datang dari unit kerja di lingkungan Universitas Nasional akan diterima Staf Kantor Sekretariat Rektorat.

b. Kemudian staf akan serahkan surat keluar kepada Kepala Kantor Sekretariat Rektorat untuk diperiksa dan untuk di ACC. Bilamana surat keluar tersebut belum layak untuk dikeluarkan maka surat dikembalikan ke asal pembuat surat keluar untk diprbaiki

c. Jika surat lulus ACC Kepala Kantor Sekretariat Retorat surat akan diserahkan kepada Pimpinan (Rektor) untuk ACC ulang.

d. Jika surat lulus ACC, surat langsung ditandatangani, namun jika surat tidak lulus ACC pimpinan, maka surat dikembalikan ke unit kerja asal pembuat surat keluar.

e. Pimpinan mengembalikan surat yang ditandatangani ke Kantor Sekretariat Rektorat untuk di stempel dan dicatat laporannya kedalam agenda buku surat keluar, dan siap untuk dikirim.

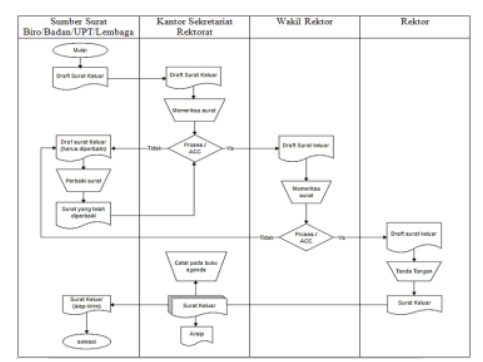

Gambar 2. Flowchart Sistem Berjalan Pengelolaan Surat Keluar

\section{Rancangan Sistem Usulan}

Rancangan sistem usulan ini dimaksudkan untuk dihasilkan rancangan sistem manajemen pengelolaan surat basis terkomputerisasi. Rancangan sistem usulan yang dibuat tidak banyak merubah dari sistem pengelolaan surat manual, namun lebih difokuskan pada pengarsipan data dan pendisposisian surat masuk menjadi berbasis terkomputerisasi.
Adapun berikut adalah aturan bisnis sistem usulan kepada Sekretariat Rektorat Universitas Nasional:

1) Proses Pengelolaan Surat Masuk Usulan

a. Surat datang diterima oleh Staf Kantor Sekretariat Rektorat (Administrator).

b. Administrator akan menginputkan data surat dan mengupload file surat pada menu tambah surat masuk.

c. Kemudian administrator akan melaporkan terkait adanya data surat masuk baru kepada Kepala Kantor Sekretariat untuk dicek dan dilakukan input pengisian form disposisi surat dengan meminta arahan pimpinan.

d. Setelah proses disposisi selesai, akan dilakukan pencetakan disposisi surat untuk segera di distribusikan kepada unit kerja (Badan, Biro, UPT, Kantor, Unsur Pelaksana Akademik) sesuai bidangnya yang terkait dengan isi surat untuk ditindak lanjuti.

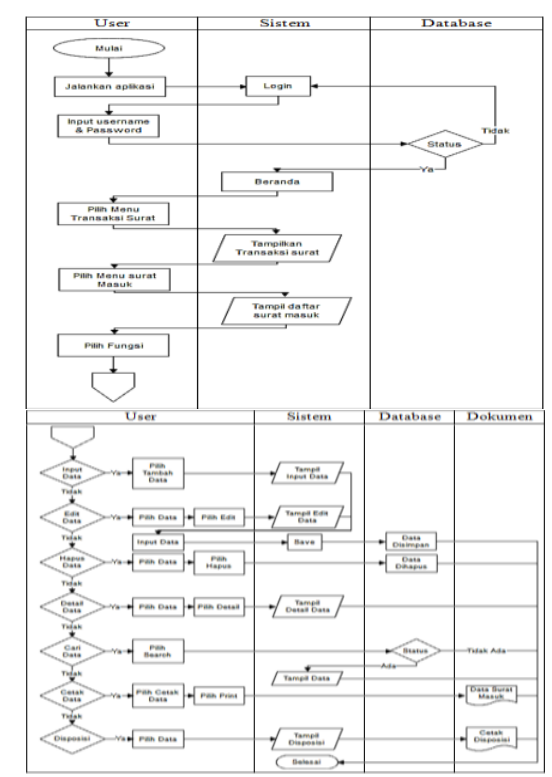

\section{Gambar 3. Flowchart Sistem Web Usulan Pengelolaan Surat Masuk}

2) Proses Pengelolaan Surat Keluar Usulan

a. Asal surat keluar datang dari unit kerja di lingkungan Universitas Nasional akan diterima Staf Kantor Sekretariat Rektorat.

b. Kemudian staf akan serahkan surat keluar kepada Kepala Kantor 
Sekretariat Rektorat untuk diperiksa dan untuk di ACC. Bilamana surat keluar tersebut belum layak untuk dikeluarkan maka surat dikembalikan ke asal pembuat surat keluar untuk diperbaiki.

c. Jika surat lulus ACC Kepala Kantor Sekretariat Retorat surat akan diserahkan kepada Pimpinan untuk di ACC ulang.

d. Jika surat lulus ACC, surat langsung ditandatangani, namun jika surat tidak lulus ACC pimpinan, maka surat dikembalikan untuk diperbaiki ke unit kerja asal pembuat surat keluar.

e. Pimpinan mengembalikan surat yang ditandatangani ke Kantor Sekretariat Rektorat untuk di stempel dan dicatat laporannya untuk di scan kedalam agenda buku surat keluar, dan siap untuk dikirim [9].

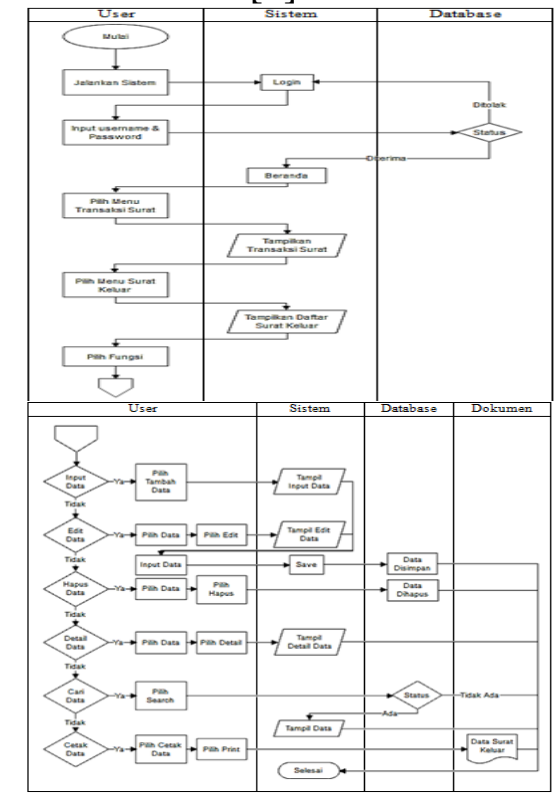

Gambar 4. Flowchart Sistem Web Usulan Pengelolaan Surat Keluar

\section{Struktur Sistem}

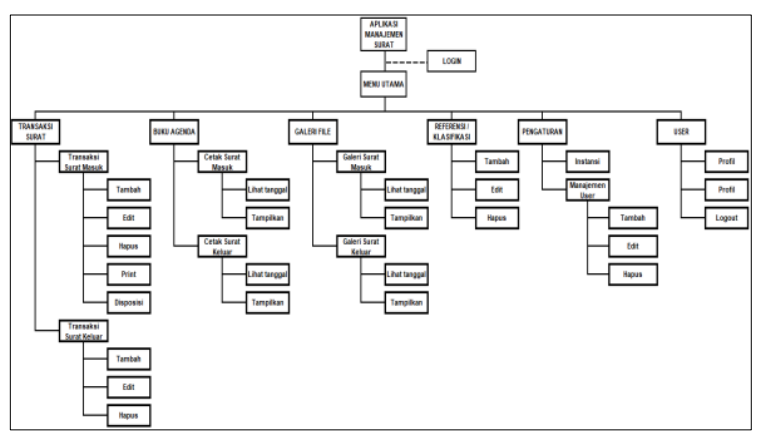

Gambar 5. Struktur Sistem Manajemen Pengelolaan Surat

Pada gambar 5 menampilkan desain struktur sistem Manajemen Pengelolaan Surat di Sekretariat Rektorat Universitas Nasional Berbasis Web.

\section{Implementasi}

Berikut merupakan tampilan Sistem Manajemen Pengelolaan Surat di Sekretariat Rektorat Universitas Nasional Berbasis Web.

1) Login

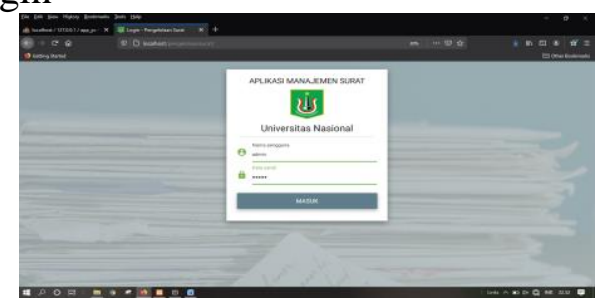

Gambar 6. Tampilan Login

Tampilan yang pertama kali terlihat Pengguna (admin/user) ketika akan mengakses sistem. Untuk masuk ke sistem menggunakan username dan password yang terdaftar.

2) Halaman Menu Utama

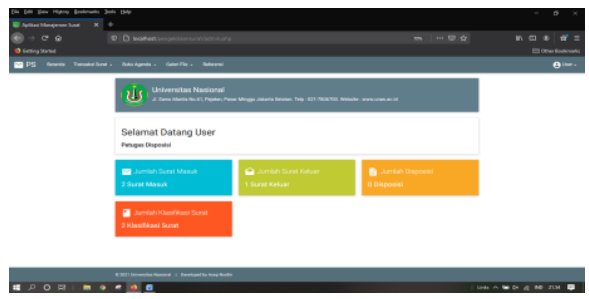

Gambar 7. Tampilan Menu Utama

Tampilan setelah pengguna berhasil login. 
3) Transaksi Surat

a. Surat Masuk

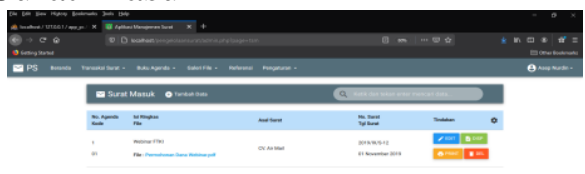

Gambar 8. Tampilan Transaksi Surat Masuk

Menampilkan data surat masuk, adapun pengontrolan surat dapat dilihat pada halaman ini seperti tambah surat, edit surat, dan hapus surat, dan disposisi surat.

b. Surat Keluar

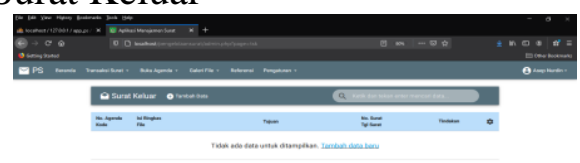

Gambar 9. Tampilan Transaksi Surat Keluar

Menampilkan data surat keluar dan pengontrolan status surat dapat dilihat pada halaman ini seperti tambah surat, edit surat, dan hapus surat.

4) Buku Agenda

a. Surat Masuk

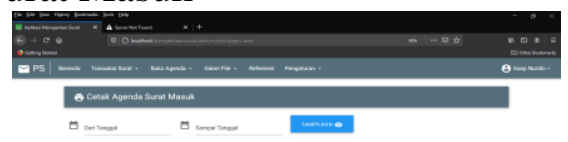
Gambar 10. Tampilan Buku Agenda Surat
Masuk

Halaman ini, menujukan metode pencarian data surat masuk. b. Surat Keluar

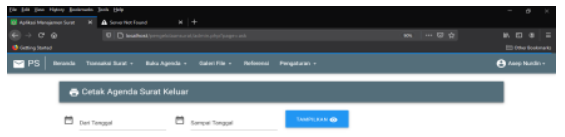

Gambar 11. Tampilan Buku Agenda Surat Keluar

Menampilkan metode pencarian data surat berdasarkan tanggal surat keluar.

5) Galeri File / Arsip Surat

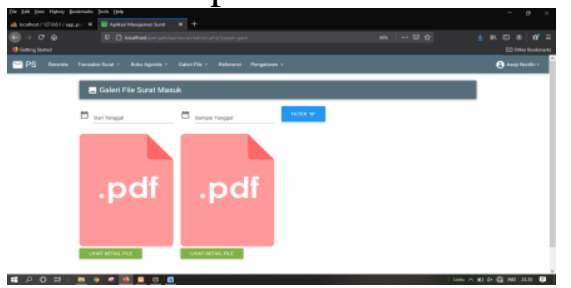

Gambar 12. Tampilan Galeri Surat

Menampilkan seluruh file surat yang tersimpan pada sistem, pada menu ini tersedia metode pencarian berdasarkan tanggal surat masuk / surat keluar.

6) Halaman Menu Klasifikasi/Referensi

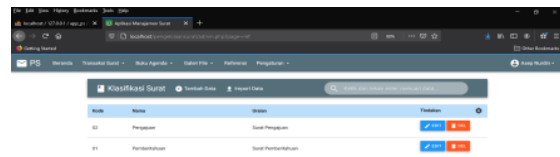

Gambar 13. Tampilan Referensi

Halaman ini, merupakanan kategori berdasarkan jenis surat.

7) Halaman Menu Pengaturan

a. Manajemen Instansi

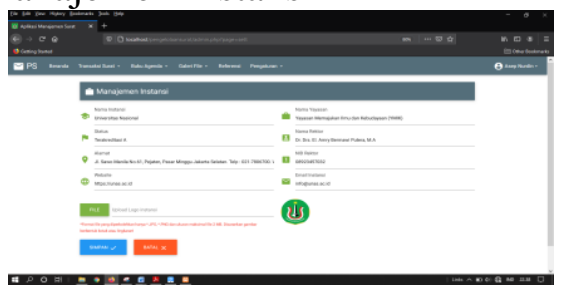

Gambar 14. Tampilan Manajemen Instansi

Halaman ini menampilkan data dari instansi Universitas Nasional. 


\section{b. Manajemen User}

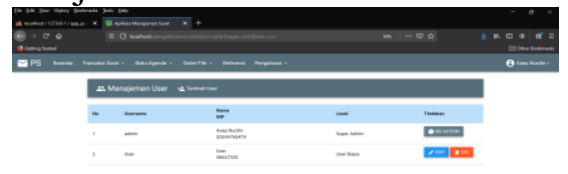

Gambar 15. Tampilan Manajemen User

Halaman ini, menampilkan daftar pengguna yang dapat mengakses sistem. Pada halaman ini, menampilkan bentuk form input pengguna baru yang dapat mengakses sistem.

8) Halaman Cetak Disposisi Surat

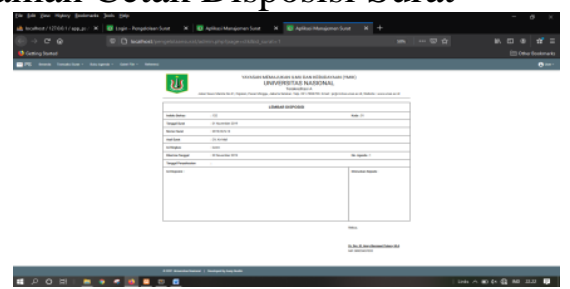

Gambar 16. Tampilan Cetak Disposisi

Merupakan tampilan output dari sistem disposisi surat untuk distribusikan.

\section{Pengujian Sistem}

Dalam pengujian penulis menggunakan dua jenis prosedur :

\section{1) Black Box Testing}

Pengujian jenis ini dilakukan dengan cara memeriksa fungsional, mengamati hasil eksekusi melalui suatu data uji software yang dibangun.

\section{Tabel 2. Analisa Hasil Black Box Testing}

\begin{tabular}{clc}
\hline No. & \multicolumn{1}{c}{ Unjuk Kerja } & Hasil Pengujian \\
\hline 1 & Menampilkan Login & $\sqrt{ }$ berhasil \\
2 & Menampilkan Menu Utama & $\sqrt{ }$ berhasil \\
3 & Menampilkan Transaksi Surat & $\sqrt{ }$ berhasil \\
4 & Menampilkan Buku Agenda & $\sqrt{ }$ berhasil \\
5 & Menampilkan Galeri File & $\sqrt{ }$ berhasil \\
6 & Menampilkan Referensi & $\sqrt{ }$ berhasil \\
7 & Menampilkan Pengaturan & $\sqrt{ }$ berhasil \\
8 & Menampilkan Lembar Disposisi & $\sqrt{ }$ berhasil \\
\hline
\end{tabular}

Dari tabel 2 diatas, tahapan analis sistem ini telah mendapatkan gambaran jelas bahwa sistem manajemen pengelolaan surat ini memenuhi tujuan.

\section{2) White Box Testing}

Pengujian jenis kedua ini adalah dengan melihat kedalam file mengamati kode-kode program, kemudian dianalisis akan kemungkinan adanya kesalahan atau tidak.

a. Login

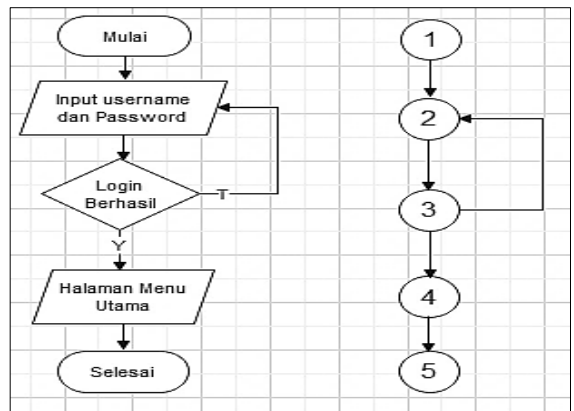

Gambar 17. Flowchart \& flowgraph Login.

- Cyclomatic Complexity dari Edge dan Node pada gambar 17, dimana nilai Edge $(\mathrm{E})=5$ dan nilai Node $(\mathrm{N})=5$, maka :

$$
\begin{aligned}
\mathrm{V}(\mathrm{G}) & =\mathrm{E}-\mathrm{N}+2 \\
& =5-5+2 \\
& =2
\end{aligned}
$$

Maka Path berjumlah sebanyak 2 Path

- Predicate Node (P) pada gambar 17, dimana $\mathrm{P}$ merupakan jumlah logika, $\mathrm{P}=1$

$$
\begin{aligned}
\mathrm{V}(\mathrm{G}) & =\mathrm{P}+1 \\
& =1+1 \\
& =2
\end{aligned}
$$

Region (R) pada gambar 17 adalah 2.

- Path-path pada gambar $17 \mathrm{~d}$ atas adalah:

$$
\begin{array}{ll}
\text { P.1 } & =1-2-3-4-5 \\
\text { P.2 } & =1-2-3-2-3-4-5
\end{array}
$$

b. Menu Utama

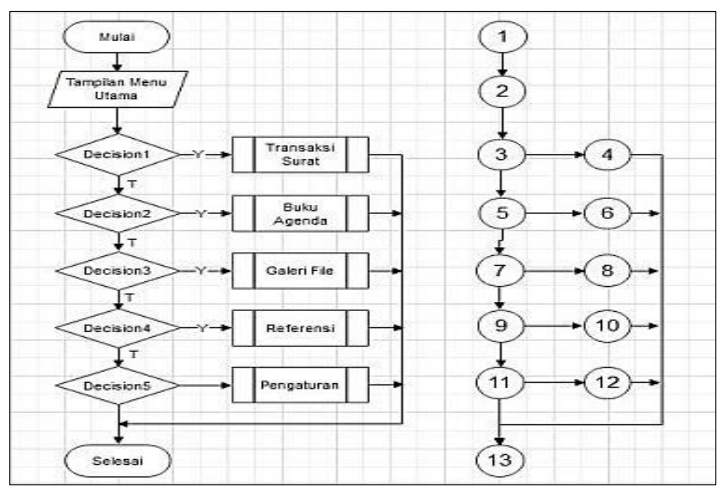

Gambar 18. Flowchart \& flowgraph Menu Utama 
- Cyclomatic Complexity dari Edge dan Node pada gambar 18, dimana nilai Edge $(E)=19$ dan nilai Node $(N)=13$, maka :

$$
\begin{aligned}
\mathrm{V}(\mathrm{G}) & =\mathrm{E}-\mathrm{N}+2 \\
& =17-13+2 \\
& =6
\end{aligned}
$$

Maka Path berjumlah sebanyak 6 Path

- Predicate Node $(\mathrm{P})$ pada gambar 18 , dimana $\mathrm{P}$ merupakan jumlah logika, $\mathrm{P}=5$

$$
\begin{aligned}
\mathrm{V}(\mathrm{G}) & =\mathrm{P}+1 \\
& =5+1 \\
& =6
\end{aligned}
$$

Region (R) pada gambar 18 adalah 6.

- Path-path pada gambar $18 \mathrm{~d}$ atas adalah:

$$
\begin{array}{ll}
\text { P.1 } & =1-2-3-4-13 \\
\text { P.2 } & =1-2-3-5-6-13 \\
\text { P.3 } & =1-2-3-5-7-8-13 \\
\text { P.4 } & =1-2-3-5-7-9-10-13 \\
\text { P.5 } & =1-2-3-5-7-9-11-12-13 \\
\text { P.6 } & =1-2-3-5-7-9-11-13
\end{array}
$$

c. Transaksi Surat

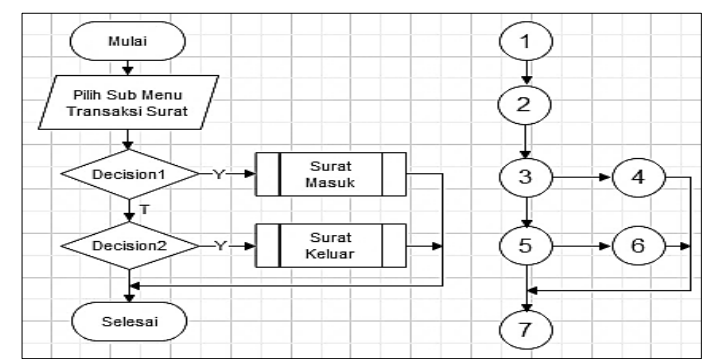

\section{Gambar 19. Flowchart \& flowgraph Transaksi Surat.}

- Cyclomatic Complexity dari Edge dan Node pada gambar 19, dimana nilai Edge $(\mathrm{E})=8$ dan nilai Node $(\mathrm{N})=7$, maka :

$$
\begin{aligned}
\mathrm{V}(\mathrm{G}) & =\mathrm{E}-\mathrm{N}+2 \\
& =8-7+2 \\
& =3
\end{aligned}
$$

Maka Path berjumlah sebanyak 3 Path

- Predicate Node $(\mathrm{P})$ pada gambar 19, dimana $\mathrm{P}$ merupakan jumlah logika, $\mathrm{P}=2$

$$
\begin{aligned}
\mathrm{V}(\mathrm{G}) & =\mathrm{P}+1 \\
& =2+1 \\
& =3
\end{aligned}
$$

Region (R) pada gambar 19 adalah 3.

- Path-path pada gambar $19 \mathrm{~d}$ atas adalah:

$$
\text { P.1 = 1-2-3-4-7 }
$$

$$
\begin{array}{ll}
\text { P.2 } & =1-2-3-5-6-7 \\
\text { P.3 } & =1-2-3-5-7
\end{array}
$$

d. Buku Agenda

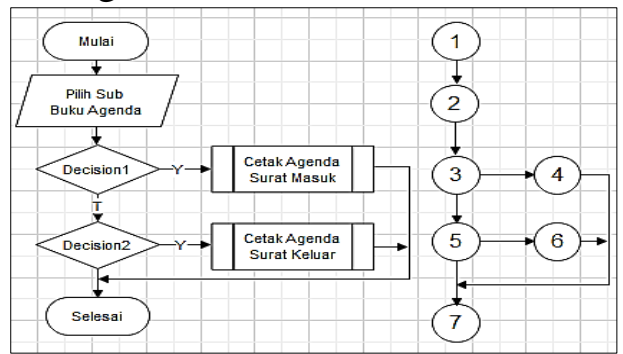

\section{Gambar 20. Flowchart \& flowgraph Buku Agenda.}

- Cyclomatic Complexity dari Edge dan Node pada gambar 20, dimana nilai Edge $(\mathrm{E})=8$ dan nilai Node $(\mathrm{N})=7$, maka :

$$
\begin{aligned}
\mathrm{V}(\mathrm{G}) & =\mathrm{E}-\mathrm{N}+2 \\
& =8-7+2 \\
& =3
\end{aligned}
$$

Maka Path berjumlah sebanyak 3 Path

- Predicate Node $(\mathrm{P})$ pada gambar 20, dimana $\mathrm{P}$ merupakan jumlah logika, $\mathrm{P}=2$

$$
\begin{aligned}
\mathrm{V}(\mathrm{G}) & =\mathrm{P}+1 \\
& =2+1 \\
& =3
\end{aligned}
$$

Region (R) pada gambar 20 adalah 3.

- Path-path pada gambar $20 \mathrm{~d}$ atas adalah:
P.1 = 1-2-3-4-7
P. $2=1-2-3-5-6-7$
P.3 $=1-2-3-5-7$

e. Galeri File

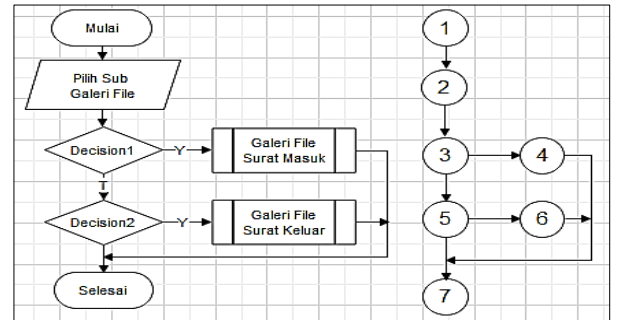

Gambar 21. Flowchart \& flowgraph Galeri File

- Cyclomatic Complexity dari Edge dan Node pada gambar 21, dimana nilai Edge $(E)=8$ dan nilai Node $(N)=7$, maka :

$$
\begin{aligned}
\mathrm{V}(\mathrm{G}) & =\mathrm{E}-\mathrm{N}+2 \\
& =8-7+2
\end{aligned}
$$




$$
=3
$$

Maka Path berjumlah sebanyak 3 Path

- Predicate Node $(\mathrm{P})$ pada gambar 21, dimana $\mathrm{P}$ merupakan jumlah logika, $\mathrm{P}=2$

$$
\begin{aligned}
\mathrm{V}(\mathrm{G}) & =\mathrm{P}+1 \\
& =2+1 \\
& =3
\end{aligned}
$$

Region (R) pada gambar 21 adalah 6.

- Path-path pada gambar $21 \mathrm{~d}$ atas adalah:
P.1 = 1-2-3-4-7
P. $2=1-2-3-5-6-7$
P.3 $=1-2-3-5-7$

f. Referensi

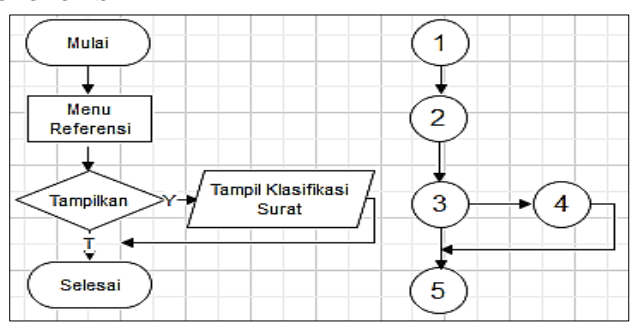

\section{Gambar 22. Flowchart \& flowgraph Referensi}

- Cyclomatic Complexity dari Edge dan Node pada gambar 22, dimana nilai Edge $(\mathrm{E})=5$ dan nilai Node $(\mathrm{N})=5$, maka :

$$
\begin{aligned}
\mathrm{V}(\mathrm{G}) & =\mathrm{E}-\mathrm{N}+2 \\
& =5-5+2 \\
& =2
\end{aligned}
$$

Maka Path berjumlah sebanyak 2 Path

- Predicate Node $(\mathrm{P})$ pada gambar 22, dimana $\mathrm{P}$ merupakan jumlah logika, $\mathrm{P}=1$

$$
\begin{aligned}
\mathrm{V}(\mathrm{G}) & =\mathrm{P}+1 \\
& =1+1 \\
& =2
\end{aligned}
$$

Region (R) pada gambar 22 adalah 2.

- Path-path pada gambar $22 \mathrm{~d}$ atas adalah:

$$
\text { P.1 = 1-2-3-5 }
$$$$
\text { P. } 2=1-2-3-4-5
$$

g. Pengaturan

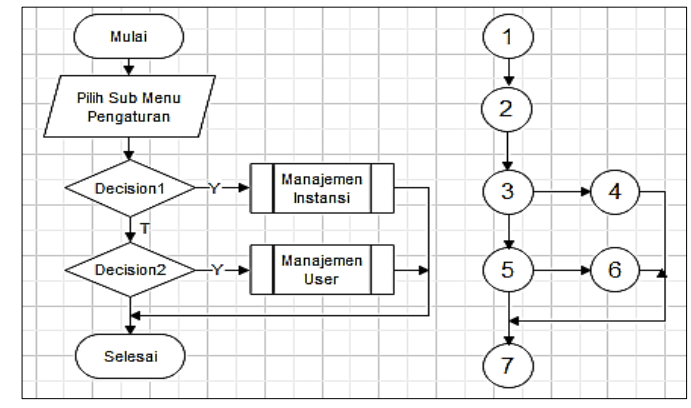

Gambar 23. Flowchart \& flowgraph Menu Pengaturan

- Cyclomatic Complexity dari Edge dan Node pada gambar 23, dimana nilai Edge $(\mathrm{E})=8$ dan nilai Node $(\mathrm{N})=7$, maka :

$$
\begin{aligned}
\mathrm{V}(\mathrm{G}) & =\mathrm{E}-\mathrm{N}+2 \\
& =8-7+2 \\
& =3
\end{aligned}
$$

Maka Path berjumlah sebanyak 3 Path

- Predicate Node $(\mathrm{P})$ pada gambar 23, dimana $\mathrm{P}$ merupakan jumlah logika, $\mathrm{P}=2$

$$
\begin{aligned}
\mathrm{V}(\mathrm{G}) & =\mathrm{P}+1 \\
& =2+1 \\
& =3
\end{aligned}
$$

Region (R) pada gambar 23 adalah 3.

- Path-path pada gambar $23 \mathrm{~d}$ atas adalah:

$$
\begin{array}{ll}
\text { P.1 } & =1-2-3-4-7 \\
\text { P.2 } & =1-2-3-5-6-7 \\
\text { P.3 } & =1-2-3-5-7
\end{array}
$$

Tabel 3. Rekapitulasi Hasil Whitebox Testing

\begin{tabular}{lccc}
\hline \multicolumn{1}{c}{ Flowgraph } & $\begin{array}{c}\text { Cyclomatic } \\
\text { Complexity }\end{array}$ & Region (R) & $\begin{array}{c}\text { Independen } \\
\text { Path }\end{array}$ \\
\hline a) Login & 2 & 2 & 2 \\
b) Menu Utama & 6 & 6 & 6 \\
c) Transaksi Surat & 3 & 3 & 3 \\
d) Buku Agenda & 3 & 3 & 3 \\
e) Galeri File & 3 & 3 & 3 \\
f) Referensi & 2 & 2 & 2 \\
g) Pengaturan & 3 & 3 & 3 \\
\hline \multicolumn{1}{c}{ Jumlah } & $\mathbf{2 2}$ & $\mathbf{2 2}$ & $\mathbf{2 2}$ \\
\hline
\end{tabular}

Pada tabel 3 diatas, berdasarkan hasil pengujian yang didapatkan bernilai sama untuk jumlah Cyclomatic Complexity $=22$, Region $=22$, dan Independent path $=22$, maka ditarik kesimpulan dari hasil pengujian tersebut menunjukan bahwa alur logika sistem manajemen pengelolaan surat di rektorat berbasis web ini sudah benar dan 
sesuai dengan logika yang ada pada kode program, serta bebas dari kesalahan.

\section{SIMPULAN}

1. Sistem manajemen pengelolaan surat berasis web dirancang sebagai sarana sistem informasi pada Kantor Sekretariat Rektorat Universitas Nasional, untuk memberi manfaat untuk memperbaiki sistem manual yang ada sehingga pengelolaan surat menjadi lebih efisien; Pencarian dan Penyimpanan menjadi lebih mudah; dan Pendisposisian surat menjadi lebih cepat.

2. Pada uji Black Box didapat hasil dimana sistem manajemen pengelolaan surat ini berbasis web ini berjalan dan telah memenuhi tujuan penulisan. Dari hasil pengujian White Box didapat hasil yang bernilai sama untuk jumlah Cyclomatic Complexity city $(\mathrm{CC})=22$, Region $(\mathrm{R})=$ 22 dan Independent Path $=22$, artinya ini menunjukan bahwa alur logika sistem manajemen pengelolaan surat di rektorat berbasis web ini sudah benar dan sesuai, serta bebas dari kesalahan.

\section{DAFTAR PUSTAKA}

[1] H. T. SIHOTANG, "Sistem Informasi Pengagendaan Surat Berbasis Web Pada Pengadilan Tinggi Medan," vol. 3, no. 1, pp. 6-9, 2019, doi: 10.31227/osf.io/bhj5q.

[2] S. Aji, Migunani, and F. N. Hakim, "Rancang Bangun Sistem Informasi Disposisi Surat Berbasis Web (Studi Kasus Kementerian Pekerjaan Umum)," Indones. J. Netw. Secur., vol. 3, no. 3, pp. 25-32, 2014.

[3] B. Anoraga, P. Nandari Bambang Eka, and . Sukadi, "Aplikasi Sistem Pengelolaan Surat Pada Kantor Desa Jetis Lor," Speed - Indones. J. Comput. Sci., vol. 11, no. 2014: IJCSS-Accepted Paper, pp. 66-71, 2014, [Online]. Available: http://ejournal.unsa.ac.id/index.php/sp eed/article/view/892.
[4] M. Hatta, M. M. Anwar, I. N. Diana, and M. H. Amarul M, "Perancangan Sistem Informasi Pengarsipan Dan Disposisi Surat Berbasis Web Dengan Menggunakan Framework Codeigniter," SCAN - J. Teknol. Inf. dan Komun., vol. 14, no. 2, 2019, doi: 10.33005/scan.v14i2.1481.

[5] G. Purnama Sari, J. Marzal, and dan Mauladi, "Rancang Bangun Sistem Informasi Persuratan Dan Disposisi Elektronik Universitas Jambi," JUSS (Jurnal Sains dan Sist. Informasi), vol. 1, no. 1, pp. 20-29, 2018, [Online]. Available: https://onlinejournal.unja.ac.id/JUSS/article/view/4 639.

[6] O. S. Rifai, F. Amrullah, F. T. Informasi, U. M. Malang, F. T. Informasi, and U. M. Malang, "Perancangan Sistem Informasi Pengelolaan Administrasi Surat," Semin. Nas. Sist. Inf. 2018, 9 Agustus 2018 Fak. Teknol. Inf. - UNMER Malang, vol. 2, no. 1, pp. 1229-1238, 2018, [Online]. Available: https://jurnalfti.unmer.ac.id/index.php/ senasif/article/download/186/155.

[7] C. T. Pratala, E. M. Asyer, I. Prayudi, and A. Saifudin, "Pengujian White Box pada Aplikasi Cash Flow Berbasis Android Menggunakan Teknik Basis Path," J. Inform. Univ. Pamulang, vol. 5, no. 2, p. 111, 2020, doi: 10.32493/informatika.v5i2.4713.

[8] H. Trizaka, D. S. Rusdianto, and A. H. Brata, "Pengembangan sistem aplikasi persuratan elektronik berbasis web di fakultas ilmu komputer ( FILKOM ) Universitas Brawijaya," J. Pengemb. Teknol. Inf. dan Ilmu Komput., vol. 3, no. 5, pp. 5115-5121, 2019, [Online]. Available: $\mathrm{http}: / / \mathrm{j}-$ ptiik.ub.ac.id/index.php/jptiik/article/download/5424/2545. 